\title{
MicroRNAs in Hypertrophic, Arrhythmogenic and Dilated Cardiomyopathy
}

\author{
Enrica Chiti ${ }^{1}$ (D) Marco Di Paolo ${ }^{2}$, Emanuela Turillazzi ${ }^{2}$ and Anna Rocchi ${ }^{2, *}$ \\ 1 Institute of Life Science, Scuola Superiore Sant'Anna, 56124 Pisa, Italy; enricachiti@gmail.com \\ 2 Department of Surgical Pathology, Medical, Molecular and Critical Area, Institute of Legal Medicine, \\ University of Pisa, Via Roma 55, 56126 Pisa, Italy; marco.dipaolo@unipi.it (M.D.P.); \\ emanuela.turillazzi@unipi.it (E.T.) \\ * Correspondence: anna.rocchi@unipi.it
}

check for updates

Citation: Chiti, E.; Di Paolo, M.; Turillazzi, E.; Rocchi, A. MicroRNAs in Hypertrophic, Arrhythmogenic and Dilated Cardiomyopathy. Diagnostics 2021, 11, 1720. https://doi.org/10.3390/ diagnostics11091720

Academic Editor: Maria I. Dorobantu

Received: 20 July 2021

Accepted: 15 September 2021

Published: 19 September 2021

Publisher's Note: MDPI stays neutral with regard to jurisdictional claims in published maps and institutional affiliations.

Copyright: (c) 2021 by the authors. Licensee MDPI, Basel, Switzerland. This article is an open access article distributed under the terms and conditions of the Creative Commons Attribution (CC BY) license (https:/ / creativecommons.org/licenses/by/ $4.0 /)$.

\begin{abstract}
MicroRNAs (miRNAs) are a class of non-coding RNAs of about 20 nucleotides in length, involved in the regulation of many biochemical pathways in the human body. The level of miRNAs in tissues and circulation can be deregulated because of altered pathophysiological mechanisms; thus, they can be employed as biomarkers for different pathological conditions, such as cardiac diseases. This review summarizes published findings of these molecular biomarkers in the three most common structural cardiomyopathies: human dilated, arrhythmogenic and hypertrophic cardiomyopathy.
\end{abstract}

Keywords: microRNAs; biomarkers; inherited cardiomyopathies; dilated cardiomyopathy; arrhythmogenic cardiomyopathy; hypertrophic cardiomyopathy

\section{Introduction}

Cardiomyopathies are a very heterogeneous group of cardiac diseases, and the inherited forms have a prevalence of 1:250 to 1:5000 in the general population depending on the subtype [1], representing a frequent cause of cardiac arrest and sudden cardiac death (SCD), especially in the young [2].

Genetically inherited cardiomyopathies represent a significant percentage of cardiovascular disorders [3]. The main inherited cardiomyopathies are hypertrophic cardiomyopathy (HCM), arrhythmogenic cardiomyopathy (ACM), and dilated cardiomyopathy (DCM) [4].

In the last twenty years, important developments have been made in the understanding of the underlying pathogenetic mechanisms of these cardiac diseases.

Only a small percentage of patients with genetically inherited cardiomyopathies carry known genetic mutations, therefore, there is the possibility that other mechanisms are implicated in their development.

Several circulating and cardiac miRNAs have been found deregulated in genetic cardiomyopathies [5,6].

MiRNAs are biomolecules with a crucial role in the physiological development of the heart and are involved in cardiovascular diseases such as coronary artery diseases (CAD), leading SCD cause in adult subjects [7], heart failure and left ventricular hypertrophy [8], atrial fibrillation [9] and stroke [10].

MiRNAs are small non-coding RNAs (about $20 \mathrm{nt}$ in length) that regulate the gene expression at post-transcriptional level. They bind complementary mRNA sequences silencing them by preventing protein synthesis or via degradation through mRNA cleavage. Imperfect base-pairing results in repression of mRNA translation while perfect base pairing determines mRNA cleavage. MiRNAs maturation starts in the nucleus with primary miRNAs (pri-miRNAs) which are processed into pre-miRNAs by Drosha and then exported into the cytoplasm by exportin 5 . RNase III enzyme cleaved pre-miRNAs in duplex miRNA of 22 nucleotides in length: one strand is incorporated into the RNA-induced silencing 
complex (RISC) while the other strand is normally degraded. Mature miRNA incorporated in RISC is less susceptible to degradation processes [11].

The human genome encodes more than 1900 miRNAs, as reported by the biological database MiRbase (www.mirbase.org).

Most miRNAs are located within the cell, but some of them are present in various body fluids and are called circulating miRNAs [12].

Circulating miRNAs are promising biomarkers, highly stable at extreme conditions of $\mathrm{pH}$, chemical treatments and temperature. Moreover, circulating miRNAs are preserved from RNAse activity because they are carried by RNA-binding proteins in extracellular vesicles and lipoprotein $[13,14]$.

Impaired miRNA expression is implicated in various disease states including cancer [15], metabolism disorders [16], and several neurodegenerative disorders [17].

The role of these biomolecules has also been strongly investigated in heart biology. Several studies reported miRNAs involvement in cardiovascular diseases such as heart failure and left ventricular hypertrophy [8] or atrial fibrillation [9]. Their expression levels (in circulation and/or in cardiac tissue) can be found deregulated in pathological conditions [5].

This review summarizes the latest miRNAs studies conducted on human samples of the most common cardiomyopathies.

\section{Article Selection}

Literature search was performed on PUBMED and Google Scholar databases. "Human cardiomyopathy", "Hypertrophic cardiomyopathy", "HCM phenocopies" "Dilated cardiomyopathy", "Arrhythmogenic cardiomyopathy" and "miRNAs" terms were combined to detect all the papers that investigated miRNAs expression in human samples of the three most frequent human structural cardiomyopathies. Finally, articles were selected after initial screening by title and abstract and then by full-text evaluation.

\section{3. miRNAs as Potential Biomarkers in Hypertrophic Cardiomyopathy}

Hypertrophic cardiomyopathy (HCM) is a structural cardiac disease characterized by left ventricular hypertrophy and a non-dilated ventricle in absence of other diseases able to determine the degree of hypertrophy. Cardiac myocytes are separated by interstitial fibrotic areas and lose their shape and their normal parallel alignment [18]. Disarray is a typical structural microscopic characteristic of HCM. In adult subjects, HCM is characterized by a wall thickness $\geq 15 \mathrm{~mm}$ in one or more LV myocardial segments, measured by different imaging technique types (i.e., echocardiography, computed tomography, or cardiac magnetic resonance). More limited hypertrophy (13-14 mm) in different LV sections can be diagnostic in first-degree relatives of a patient with HCM [19-21]. HCM is an autosomal dominant disease, characterized by high heterogeneity and variable expressivity. Up to $60 \%$ of $\mathrm{HCM}$ patients carry mutations in genes encoding sarcomeric proteins [22,23]. The remaining $40 \%$ of $\mathrm{HCM}$ patients are sporadic.

Epigenetic changes, such as those changes performed by miRNAs, could be involved in the pathogenesis of HCM. Different studies analyzed miRNAs' role in HCM development and cardiac remodeling.

\subsection{Circulating miRNAs in HCM}

Roncarati et al., aiming to characterize the circulating miRNA profile in a group of $41 \mathrm{HCM}$ subjects, analyzed 21 miRNAs directly involved in angiogenesis, fibrosis, apoptosis, hypertrophy, and smooth muscle cell biology. miR-214, miR-16, and miR-1 were downregulated while miR-27a, miR-199a-5p, miR-26a, miR-145, miR-133a, miR-143, miR-199a-3p, miR-126-3p, miR-29a, miR-155, miR-30a, and miR-21 were upregulated in patients compared to controls. Besides this the authors, evaluating the correlation between miRNAs and left ventricular (LV) parameters (fibrosis and hypertrophy), found that 
miR-27a, miR-29a, and miR-199a-5p correlate with cardiac hypertrophy. Moreover, high levels of miR-29a significantly correlate with both cardiac fibrosis and hypertrophy [24].

Fang et al. performed an array of 84 circulating miRNAs in eight HCM patients and selected 14 miRNAs significantly upregulated in patients with diffuse myocardial fibrosis compared to controls. These 14 miRNAs, together with miR-29a-3p and miR-133a-3p, which have a well-established role in cardiac fibrosis, were further validated in a group of 55 HCM patients. The authors found low levels of miR-373-3p and miR-96-5p and high levels of 14 miRNAs (miR-18a-5p, miR-146a-5p, miR-30d-5p, miR-17-5p, miR-200a-3p, miR-19b-3p, miR-21-5p, miR-193-5p, miR-10b-5p, miR-15a-5p, miR-192-5p, miR-296-5p, miR-29a-3p, and miR-133a-3p) in patients with HCM and diffuse myocardial fibrosis compared to patients with non-diffuse myocardial fibrosis [25].

Derda et al. analyzed eight circulating miRNAs selected from the literature (miR-1, miR-21, miR-29a, miR-29b, miR-29c, miR-133a, miR-155, and miR-499) in four different groups of subjects (23 patients with non-obstructive HCM, 28 patients with obstructive HCM, 47 subjects with cardiac hypertrophy due to aortic stenosis, and 22 controls). miR-155 was downregulated in both HCM subgroups (but not in patients with aortic stenosis) while miR-29a was significantly upregulated only in obstructive HCM patients. High levels of circulating miR-29c exclusively characterized the aortic stenosis group. In the same study the researchers evaluated circulating miRNAs levels in obstructive HCM due to sarcomeric mutations in MHY7 and MYBPC3 genes: miR-29a levels were increased in obstructive HCM carrying MYH7 mutation but not in MYBPC3 patients [26].

Zhou et al. evaluated the expression levels of some potentially relevant miRNAs and long non-coding RNAs (lncRNAs) in serum samples of HCM patients with and without fibrosis and found high levels of miR-29a in the fibrosis HCM group compared to subjects without fibrosis. In contrast, patients without fibrosis showed high levels of the lncRNA MIAT. Moreover, wild-type MIAT cells, transfected with miR-29a mimics, showed a suppressed luciferase activity, suggesting a negative regulation of miR-29a by MIAT [27].

Gudkova et al. found instead that miR-21 levels were higher in HCM patients than in controls [28].

\subsection{Cardiac miRNAs in HCM}

miR-590-5p and miR-92a were higher while miR-1, miR-133b, miR-191, miR-208b, miR-218, miR-30b, miR-374, miR-454, and miR-495 were lower in the cardiac tissues of five HCM subjects (three with left ventricular hypertrophy caused by heart valve disease and two with MYH7 mutations) compared to controls [29].

Wang et al. reported higher levels of cardiac miR-221 in HCM compared to controls [30].

Leptidis et al. evaluated five heart-failure HCM patients and found twenty miRNAs (miR-1-3p, miR-23a-3p, miR-23b-3p, miR-24-3p, miR-29b-3p, miR-30d-5p, miR-125a-5p, miR-126-3p, miR-133a-3p, miR-143-3p, miR-145-5p, miR-193b-3p, miR-197-3p, miR-331-3p, miR-342-3p, miR-361-5p, miR-365-3p, miR-455-3p, miR-1975-3p, miR-1978) upregulated in patients compared to controls [31].

Contrasting results were obtained by Liu et al. about miR-29 family levels, with no differences between HCM patients and controls [32].

Kuster et al. described a specific miRNA HCM profile in six patients carrying MYBPC3 mutation. miR-10b and miR-10b* were downregulated while miR-184, miR-497, miR-204, miR-34b*, miR-222* were upregulated in HCM patients compared to controls. In silico mRNA target prediction demonstrated that many of the miRNA target genes were related to $\beta$-adrenergic pathway (a part of cardiac hypertrophic signaling) [33].

Song L. et al. found that miR-21, miR-130b, and miR-132 were significantly upregulated, whereas miR-451, miR-363, miR-150, miR-3141, miR-144, miR-144*, miR-1395p, miR-139-3p, miR-1246, miR-486-3p were downregulated compared to controls [34]. miR-139-5p downregulation in human HCM cardiac tissue was also confirmed by Ming and colleagues [35]. 
Low levels of miR-27a and miR-1-3p characterized instead transplanted hearts of both HCM and DCM subjects. In particular, miR-1-3p is inversely correlated with LV end-diastolic diameter and directly with LV ejection fraction and [36].

Sun et al. evaluating 367 differentially expressed miRNAs in five HCM cardiac tissues found miR-20 as one of the highly expressed miRNAs in the HCM group compared to controls [37].

More recently, Huang et al. found lower levels of miR-19b and miR-155 and higher levels of miR-221, miR-222, and miR-433 in 42 obstructive HCM patients compared to controls. In particular, cardiac miR-221 positively correlates with myocardial fibrosis while miR-19b inversely correlates with myocardial fibrosis [38].

As shown in Table 1, only a few miRNAs overlap between studies on human HCM (i.e., miR-29, miR-21, miR-133, and miR-1).

In particular, miR-29 family is one of the most commonly reported miRNAs in HCM patients. High levels of circulating miR-29a distinguish HCM patients from controls [24-27] and miR-29b upregulation also characterizes the cardiac tissue of end-stage HCM patients [31].

High levels of miR-21 are reported in HCM blood [24,25,28] and cardiac tissue [31].

High levels of miR-133 are reported in blood [24,25] and myocardium [31]. Contrary results were obtained by Palacin et al. [29].

miR-1 downregulation characterized both blood [24] and HCM cardiac tissue [29,36]. In contrast, Leptidis showed miR-1 upregulation in cardiac tissue [31].

\section{3. miRNAs and HCM Phenocopies}

A phenocopy is a phenotype that can falsely mimic the disease. Different genetic disorders not determined by sarcomeric mutations have been associated with severe left ventricular hypertrophy and are called HCM phenocopies.

Another possible role of miRNAs could be the contribution in differential diagnosis between HCM and phenocopies.

Fabry disease (FD), an X-linked lysosomal storage disorder, is characterized by mutations in the GLA gene, encoding the $\alpha$-galactosidase A enzyme, causing the absence or reduction of the activity of the lysosomal enzyme and a subsequent lysosomal accumulation of globotriaosilceramide (Gb3) and other glycosphingolipids in different cell types, such as cardiomyocytes. Fabry disease can involve the heart mimicking HCM.

Recently, Cammarata et al. found that some circulating miRNAs could be used to differentiate FD from controls (divided in healthy controls and subjects with left ventricular hypertrophy). Researchers found that miR-199a-5p and miR-126-3p levels were higher in FD than in controls with left ventricular hypertrophy. Lower miR-423-5p and miR-451a levels characterized instead FD compared to controls [39].

Low levels of circulating miR-26a-5p, -21-5p, -152-5p, 1307-5p characterized FD patients after enzyme replace therapy [40].

Cardiac amyloidosis, identified by the deposition and misfolding of insoluble proteins that affect the heart, possibly leads to severe heart failure and cardiac hypertrophy.

A recent work evaluated circulating miRNA levels in patients with transthyretin amyloidosis, with senile cardiac amyloidosis, with HF with reduced ejection fraction and in controls. miR-27a levels were significantly decreased in transthyretin amyloidosis compared to controls while miR-399-3p levels were higher in senile cardiac amyloidosis compared to the other three groups [41].

Pompe disease, another HCM phenocopy, is a metabolic disease linked to mutations in the GAA gene, with a deficiency of the GAA enzyme involved in the lysosomal glycogen degradation. High levels of circulating miR-133a characterized patients affected by Pompe disease [42].

More studies are needed to discover useful miRNAs to differentiate diseases mimicking HCM phenotype from HCM itself. 
Table 1. Summary of miRNAs involved in human HCM.

\begin{tabular}{|c|c|c|c|}
\hline \multicolumn{4}{|c|}{ miRNAs in HCM } \\
\hline \multicolumn{4}{|c|}{ Circulating miRNAs } \\
\hline miRNAs & Quantitative Effect & Notes & Reference \\
\hline miR-1, miR-16, miR-214 & downregulated & & \\
\hline $\begin{array}{c}\text { miR-27a, miR-199a-5p, miR-26a, miR-145, } \\
\text { mi -133a, miR-143, miR-199a-3p, } \\
\text { miR-126-3p, miR-29a, miR-155, miR-30a, } \\
\text { miR-21 }\end{array}$ & upregulated & $\begin{array}{l}\text { miR-199a-5p, miR-27a correlates with } \\
\text { hypertrophy. miR-29a significantly } \\
\text { correlates with both cardiac fibrosis } \\
\text { and hypertrophy }\end{array}$ & [24] \\
\hline miR-373-3p, miR-96-5p & downregulated & & \\
\hline $\begin{array}{l}\text { miR-18a-5p, miR-146a-5p, miR-30d-5p, } \\
\text { miR-17-5p, miR-200a-3p, miR-19b-3p, } \\
\text { miR-21-5p, miR-193-5p, miR-10b-5p, } \\
\text { miR-15a-5p, miR-192-5p, miR-296-5p, } \\
\text { miR-29a-3p, miR-133a-3p }\end{array}$ & upregulated & $\begin{array}{l}\text { patients with HCM and diffuse } \\
\text { myocardial fibrosis }\end{array}$ & [25] \\
\hline miR-155 & downregulated & $\begin{array}{c}\text { miR-155 downregulated in obstructive and } \\
\text { non-obstructive HCM }\end{array}$ & \\
\hline miR-29a & upregulated & $\begin{array}{l}\text { miR-29a upregulated in obstructive HCM } \\
\text { with MYH7 mutations }\end{array}$ & [26] \\
\hline $\operatorname{miR}-29 \mathrm{c}$ & upregulated & miR-29c high only in aortic stenosis group & \\
\hline miR-29a & upregulated & $\begin{array}{l}\text { HCM patients with fibrosis compared to } \\
\text { HCM without fibrosis }\end{array}$ & [27] \\
\hline miR-21 & upregulated & & [28] \\
\hline \multicolumn{4}{|c|}{ Cardiac miRNAs } \\
\hline $\begin{array}{l}\text { miR-1, miR-133b, miR-191, miR-208b, } \\
\text { miR-218, miR-30b, miR-374, miR-454, } \\
\text { miR-495 }\end{array}$ & downregulated & $\begin{array}{l}\text { miR-208b downregulated in HCM due to } \\
\text { valve disease. miR-495 downregulated in } \\
\text { HCM with MYH7 mutations }\end{array}$ & [29] \\
\hline miR-590-5p, miR-92a & upregulated & & \\
\hline $\operatorname{miR}-221$ & upregulated & & [30] \\
\hline $\begin{array}{l}\text { miR-1-3p, miR-23a-3p, miR-23b-3p, } \\
\text { miR-24-3p, miR-29b-3p, miR-30d-5p, } \\
\text { miR-125a-5p, miR-126-3p, miR-133a-3p, } \\
\text { miR-143-3p, miR-145-5p, miR-193b-3p, } \\
\text { miR-197-3p, miR-331-3p, miR-342-3p, } \\
\text { miR-361-5p, miR-365-3p, miR-455-3p, } \\
\text { miR-1975-3p, miR-1978 }\end{array}$ & upregulated & $\begin{array}{l}\text { end-stage HCM patients compared } \\
\text { to controls }\end{array}$ & [31] \\
\hline miR-29 family & - & $\begin{array}{l}\text { no differences between patients } \\
\text { and controls }\end{array}$ & [32] \\
\hline $\begin{array}{l}\text { miR-10b, miR10b* miR-184, miR-497, } \\
\text { miR-204, miR-222*, miR-34* }\end{array}$ & $\begin{array}{c}\text { downregulated } \\
\text { upregulated }\end{array}$ & & [33] \\
\hline $\begin{array}{l}\text { miR-451, miR- 363, miR-150, miR-3141, } \\
\text { miR-144, miR-144*, miR-139-5p, } \\
\text { miR-139-3p, miR-1246, miR-486-3p } \\
\text { miR-21, miR-130b, miR-132 }\end{array}$ & $\begin{array}{l}\text { downregulated } \\
\text { upregulated }\end{array}$ & & {$[34]$} \\
\hline miR-139-5p & downregulated & & [35] \\
\hline $\operatorname{miR}-27 a$, miR-1-3p & downregulated & $\begin{array}{l}\text { both miRNAs were downregulated also in } \\
\text { DCM cardiac tissue. }\end{array}$ & [36] \\
\hline $\operatorname{miR}-20$ & upregulated & & [37] \\
\hline $\begin{array}{c}\text { miR-19b, miR-155 } \\
\text { miR-221, miR-222, miR-433 }\end{array}$ & $\begin{array}{l}\text { Downregulated } \\
\text { upregulated }\end{array}$ & $\begin{array}{l}\text { in obstructive HCM patients compared } \\
\text { to controls }\end{array}$ & [38] \\
\hline
\end{tabular}




\section{4. miRNAs as Potential Biomarkers in Arrhythmogenic Cardiomyopathy}

Arrhythmogenic Cardiomyopathy (ACM) is a genetic cardiac disease characterized by progressive fibrofatty substitution of the right ventricular cardiomyocytes and ventricular wall thinning. Left ventricular involvement affects more than $50 \%$ of cases [43]. Histology usually presents cardiomyocyte death, inflammation, and fibro-adipose substitution [44]. ACM is characterized by the development of ventricular arrhythmias [45] and heart failure and can be a cause of sudden cardiac death, especially in the young [46-48].

ACM diagnosis is particularly challenging, because of incomplete penetrance and variable expressivity and can be performed using different techniques, such as electrocardiography (ECG), imaging techniques (echocardiography and magnetic resonance), and genetic evaluation [49].

The majority of genetic mutations causing ACM are located in desmosomal genes as desmoplakin (DP), plakoglobin (PG), plakophilin 2 (PKP2), and desmoglein 2 (DSG2) [50].

\subsection{Circulating miRNAs in ACM}

Sommariva et al., demonstrating low levels of circulating miR-320a in $36 \mathrm{ACM}$ patients compared to idiopathic ventricular tachycardia (IVT) patients and controls, hypothesized that miR-320a could be a promising biomarker to distinguish between arrhythmogenic cardiomyopathy and IVT. Moreover, miR-320a expression seemed not to be affected by heart remodeling/changes induced by physical exertion, a recognized ACM risk factor [51].

Yamada et al. studied circulating miRNAs in 62 patients with ventricular arrhythmia (VA): 23 with idiopathic ventricular tachycardia, 28 with diagnosed ACM and 11 with borderline or possible ACM. Higher levels of miR-144-3p, miR-145-5p, miR-185-5p, and miR-494 were found in plasma samples of ACM subjects with ventricular arrhythmia compared to controls, IVT patients and subjects with suspected arrhythmogenic cardiomyopathy. High levels of miR-494 correlate with recurrent ventricular arrhythmia after ablation in ACM subjects [52].

Recently, Bueno Marinas validated six miRNAs (miR-122-5p, miR-133a-3p, miR-133b, miR-142-3p, miR-182-5p, and miR-183-5p) in blood samples $(n=90$ patients divided in ACM unaffected family members with a pathogenic variant, myocarditis, Brugada syndrome, hypertrophic cardiomyopathy and dilated cardiomyopathy). miR-122-5p, miR-182-5p, and miR-183-5p were higher in ACM compared to controls and the other cardiomyopathies, while miR-133a-3p, miR-133b, and miR-142-3p were downregulated in $\mathrm{ACM}$ than in controls and other groups [53].

\subsection{Cardiac miRNAs in ACM}

Zhang et al., in 2016, analyzed for the first time the cardiac tissue of 24 ACM patients subjected to cardiac transplant and found 12 upregulated (miR-21-3p, miR-21-5p, miR34a-5p, miR-212-3p, miR-216a, miR-584-3p, miR-1251, miR-3621, miR-3674, miR-3692-3p, miR-4286, miR-4301) and 12 downregulated miRNAs (miR-135b, miR-138-5p, miR-193b-3p, miR-302b-3p, miR-302c-3p, miR-338-3p, miR-451a, miR-491-3p, miR-575, miR-3529-5P, miR-4254, miR-4643). MiR-21-5p and miR-135b were the most significantly deregulated. Researchers also established that target genes of miR-21-5p and miR-135b were involved in the Wnt and Hippo signaling pathways (BMPR2 is related to adipogenesis and TGFBR2 is associated with fibrosis and extracellular matrix production), molecular mechanisms probably related to the ACM molecular pathophysiology, suggesting a possible role in fibrofatty substitution [54].

Rainer et al. discovered higher levels of miR-29b-3p in cardiac stromal cells involved in adipogenesis of the ACM heart compared to controls [55]. Table 2 reports miRNAs potentially involved in human ACM. 
Table 2. Summary of miRNAs potentially involved in human ACM.

\begin{tabular}{|c|c|c|c|}
\hline \multicolumn{4}{|c|}{ miRNAs in ACM } \\
\hline \multicolumn{4}{|c|}{ Circulating miRNAs } \\
\hline miRNAs & Quantitative Effect & Notes & Reference \\
\hline miR-320a & downregulated & $\begin{array}{l}\text { lower in ACM compared to IVT } \\
\text { and controls }\end{array}$ & [51] \\
\hline $\begin{array}{l}\text { miR-144-3p, miR-145-5p, miR-185-5p, and } \\
\text { miR-494 }\end{array}$ & upregulated & $\begin{array}{l}\text { ACM with ventricular arrhythmia } \\
\text { compared to controls }\end{array}$ & [52] \\
\hline $\begin{array}{l}\text { miR-122-5p, miR-182-5p, and miR-183-5p } \\
\text { miR-133a-3p, miR-133b, miR-142-3p }\end{array}$ & $\begin{array}{l}\text { Upregulated } \\
\text { downregulated }\end{array}$ & $\begin{array}{l}\text { deregulated in ACM compared to } \\
\text { controls and other cardiomyopathies }\end{array}$ & [53] \\
\hline \multicolumn{4}{|c|}{ Cardiac miRNAs } \\
\hline $\begin{array}{l}\text { miR-21-3p, miR-21-5p, miR-34a-5p, miR-212-3p, } \\
\text { miR-216a, miR-584-3p, miR-1251, miR-3621, } \\
\text { miR-3674, miR-3692-3p, miR-4286, miR-4301 }\end{array}$ & upregulated & & {$[54]$} \\
\hline $\begin{array}{c}\text { miR-135b, miR-138-5p, miR-193b-3p, } \\
\text { miR-302b-3p, miR-302c-3p, miR-338-3p, } \\
\text { miR-451a, miR-491-3p, miR-575, miR-3529-5P, } \\
\text { miR-4254, miR-4643 }\end{array}$ & downregulated & & \\
\hline miR-29b-3p & upregulated & & [55] \\
\hline
\end{tabular}

\section{5. miRNAs as Potential Biomarkers in Dilated Cardiomyopathy}

Dilated cardiomyopathy (DCM) is another structural cardiac disease associated with heart failure and high risk of sudden death [56]. DCM is characterized by left ventricular wall thinning, systolic dysfunction, and chamber dilatation but right ventricular involvement is also observed. Extracellular matrix fibrosis is an important pathological DCM modification that can contribute to heart failure [57]. Different issues, such as myocarditis, drugs, alcohol, and genetic inheritance, are involved in DCM [58]. Most of the pathogenic mutations have been found in sarcomeric and nuclear envelope genes [59,60].

Diagnosis is based primarily on the exclusion of ischemic heart disease or chronic abnormal loading conditions such as hypertension and valvular disorders [61]. Other criteria are represented by the presence of fractional shortening less than $25 \%$ ( $>2 \mathrm{SD}$ ) and / or ejection fraction less than $45 \%$ ( $>2 \mathrm{SD})$, and left ventricular end-diastolic diameter (LVEDD) greater than $117 \%$ ( $>2 \mathrm{SD}$ of the predicted value of $112 \%$ corrected for age and body surface area) [62]. An electrocardiogram is the initial cardiac screening test used for suggestive (non-confirmatory) diagnosis of DCM. Echocardiography is the first-line imaging test and cardiac magnetic resonance is used to confirm the underlying diagnosis of cardiomyopathy [63].

Endomyocardial biopsy is recommended with suspicion of myocarditis or inflammatory cardiomyopathy in selected patients.

Prognosis is poor in DCM subjects with left ventricular ejection fraction (LVEF) of less than $35 \%$ : LVEF less than 35\% is related to a high risk of sudden death [64].

Other factors, such as mitral regurgitation, fibrosis, or chamber enlargement, can worsen the prognosis [60].

The following scientific works evaluated miRNAs' function in human DCM.

\subsection{Circulating miRNAs in DCM}

Nair et al. found low levels of circulating miR-142-3p and high levels of miR-124-5p in DCM patients [65].

Low levels of the miR-548 family (in particular miR-548c) characterized DCM subjects with stable chronic heart failure [66]. 
Fan et al. identified instead high levels of miR-423-5p in heart failure DCM patients [67].

Yu et al. found that miR-185 levels were higher in DCM patients compared to controls. Furthermore, high levels of miR-185 were associated with favorable prognosis in DCM patients because this miRNA repress the B cells involved in myocardial fibrosis and myocyte injuries [68].

Wang et al. described high levels of miR-3135b, miR-3908, and miR-5571-5p in human DCM. In particular, miR-5571-5p upregulation was significantly associated with symptom severity and disease progression [69].

A study conducted on five circulating miRNAs and extracellular matrix (ECM) fibrosis demonstrated a correlation between miR-26 and miR-30 and collagen volume fraction, related to fibrosis [70].

In DCM acute heart failure patients, miR-92b-5p levels were higher than in controls [71]. Onrat et al. found high levels of miR-24-3p, miR-28-5p, miR-100-5p, miR-103-3p, miR125b5p, miR-214-3p, let-7b-5p, and let-7c-5p in ischemic and idiopathic DCM [72].

Toro et al. analyzed DCM patients with pathogenic LMNA mutations (one of the most common variants associated with familial DCM) and found increased levels of let7a-5p, miR-142-3p, miR-145-5p, and miR-454-3p compared to idiopathic DCM or LMNA controls [73]. The same group, two years later, proposed a six-miRNA panel (let-7a5p, let-7g-5p, miR-16-2-3p, miR-210-3p, miR-215-5p, and miR-629-5p) to differentiate DCM subjects with pathogenic BAG3 or LMNA variants from wild-type variant carriers. A second group of five miRNAs (miR-19b-3p, miR-29a-3p, miR-130b-3p, miR-215-5p, miR-629-5p) was proposed instead to distinguish phenotypically negative variant carriers from healthy subjects [74].

Zaragoza et al. analyzed a Spanish family affected by familial DCM due to BAG3 (BAG cochaperone 3) gene mutations: circulating miR-154-5p, miR-182-5p, miR-1249-ep, miR-3191-3p, miR-6769b-3p, and miR-6855-5p were increased in BAG3+ mutant carriers compared to BAG3 wild-type. Moreover, miR-154-5p, miR-182-5p and miR-6885-5p, correlates with systolic and diastolic blood pressure, A wave, left atrium area and length in BAG3+ mutation carriers [75].

Dziewięcka et al., in 2020, evaluated both circulating and cardiac miRNAs in left ventricular reverse remodeling (LVRR) DCM and found that only cardiac miR-133a showed a significantly increased expression in LVRR compared to non-LVRR patients [76].

A recent study conducted by Calderon-Dominguez in 2021 presented a predictive three-miRNAs model (high levels of miR-130b-3p, miR-150-5p, and miR-210-3p) that, combined with clinical variables, could distinguish idiopathic DCM with severe reduced systolic ejection fraction from patients with moderately reduced ejection fraction [77].

\subsection{Cardiac miRNAs in DCM}

Satoh et al. described higher levels of miR-21 and lower levels of let-7i, miR-126, and miR-155 in cardiac tissues of DCM patients compared to controls and patients without left ventricular dysfunction. Researchers demonstrated a relationship between low levels of let-7i and a poor clinical outcome (heart failure and death) [78]. High levels of miR-21 were also confirmed in human DCM and myocarditis animal models, highlighting a possible role of miR-21 in myocardial fibrosis development in these two cardiac diseases [79].

Greco et al. analyzed miRNA expression profiles in left ventricular biopsies from type-2 diabetic and non-diabetic subjects affected by ischemic DCM. In particular, miR-34b, miR-34c, miR-199b, and miR-210 were higher in diabetic DCM compared to controls, while miR-223 and miR-650 were higher in diabetic compared to non-diabetic DCM but lower in non-diabetic DCM compared to controls. Moreover, miR-216a resulted in upregulation in both DCM groups compared to controls. In particular, miR-216a expression inversely correlated with left ventricular ejection fraction [80].

Besler et al. observed higher miR-133a levels in inflammatory DCM without fibrosis than in patients with fibrosis. High levels of miR-133a were associated with a reduction in 
necrosis and fibrosis in myocytes and left ventricular functional recovery in inflammatory DCM [81].

Naga Prasad et al. analyzed end-stage heart failure DCM and found lower levels of miR-378, miR-1, miR-7, and miR-29b and higher levels of miR-342, miR-214, miR-125b, miR-145, and miR-181b compared to controls [82].

Wang et al. studied miRNAs profile in different cardiac regions (left, right ventricle, apex, and septum) and found higher levels of miR-21 and miR-29 family and lower levels of miR-133 family in the left and right ventricle, and the apex of DCM patients compared to controls. No significant differences were found in the miRNA profile of the septum [83].

Zhou et al. found higher levels of miR-208b in severe heart failure DCM (subjected to assist device implantation) compared to subjects with heart failure due to ischemic heart disease or myocarditis [84].

Li et al., analyzing HCM and DCM samples, demonstrated higher levels of miR-155, miR-10b, and miR-23a in both patient groups compared to controls. Different expression patterns between DCM and HCM patients were found for miR-21(upregulated in DCM), miR-214 (downregulated in DCM), and miR-27a and miR-1-3p (downregulated in HCM) [36].

Both cardiac and circulating miR-29 and miR-26 were, respectively higher and lower in the DCM cohort compared to controls. Only cardiac miR-133a was instead downregulated in patients compared to controls [85].

miR-21, a microRNA involved in the proliferation of fibroblasts and cardiac fibrosis, showed upregulation in cardiac tissue of DCM [36,78,79,83].

Contrasting results are observed for miR-29, reported as downregulated $[82,83]$ and also upregulated [85] in the cardiac tissue of DCM patients. Additionally, miR-133 reports contrasting results in cardiac tissue: it has variously been found to be downregulated $[83,85]$ and also upregulated in cardiac tissue [81].

\subsection{DCM Is Common Cardiomyopathy in Childhood}

DCM represents a relevant issue both in the adult and pediatric population but only few studies analyzed miRNAs in children affected by DCM (Table 4).

Table 3 shows that few miRNAs are in common between different studies.

Miyamoto et al. conducted a study on 55 children ( $<18$ years) and found an upregulation of circulating miR-155 and miR-636 and a downregulation of miR-639 and miR-646 in DCM patients (who were transplanted or died), compared to DCM subjects with recovered ventricular function, suggesting the four miRNAs as diagnostic and prognostic biomarkers [86].

Enes Coşkun et al. analyzed plasma of idiopathic DCM children (2-192 months) and found a significant upregulation of miR-454 and miR-518f in patients than in controls. In the DCM children group, 10 circulating miRNAs (miR-99b, miR-147, miR-155, miR-194, miR-205, miR-218 miR-302a, miR-544, miR-618, and miR-875-3p) were instead downregulated [87].

Jiao and colleagues found higher levels of let-7f-5p, let-7g-5p, miR-26a-5p, miR-27a-3p, miR-27b-3p, miR-126-3p, miR-142-5p, and miR-143-3p in serum of child DCM patients compared to controls. In particular, increased levels of miR-126-3p and let-7g associated with a decreased ejection fraction compared with no heart-failure subjects [88].

Woulfe et al. analyzed instead left ventricular tissue of pediatric idiopathic DCM, characterized by lower levels of miR-29 family compared to controls. Significant downregulation of miR-29 was related to pediatric heart failure subjects without fibrosis [89].

Due to the difficulty of tissue sampling in children, circulating miRNAs could be promising biomarkers for DCM in young patients, together with their possible use as biomarkers for risk stratification in prognosis related to young people affected by DCM. 
Table 3. Summary of miRNAs potentially involved in human DCM.

\begin{tabular}{|c|c|c|c|}
\hline \multicolumn{4}{|c|}{ miRNAs in DCM } \\
\hline \multicolumn{4}{|c|}{ Circulating miRNAs } \\
\hline miRNAs & Quantitative Effect & Notes & Reference \\
\hline miR-142-3p & downregulated & $\begin{array}{l}\text { in compensated and in congestive heart } \\
\text { failure DCM }\end{array}$ & \multirow[t]{2}{*}{ [65] } \\
\hline miR-124-5p & upregulated & & \\
\hline miR-548 & downregulated & DCM with stable chronic heart failure & {$[66]$} \\
\hline $\operatorname{miR}-423-5 p$ & upregulated & DCM-related heart failure & [67] \\
\hline miR-185 & upregulated & $\begin{array}{l}\text { upregulation linked to a favourable } \\
\text { prognosis in DCM patients }\end{array}$ & {$[68]$} \\
\hline miR-3135b, miR-3908, miR-5571-5p & upregulated & & [69] \\
\hline miR-26, miR-30 & similar levels & $\begin{array}{l}\text { chronic and new-onset DCM with and } \\
\text { without fibrosis }\end{array}$ & {$[70]$} \\
\hline miR-92b-5p & upregulated & acute heart failure due to DCM & [71] \\
\hline $\begin{array}{l}\text { miR-24-3p, miR-28-5p, miR-100-5p, } \\
\text { miR-103-3p, miR-125b5p, miR-214-3p, } \\
\text { let-7b-5p, let-7c-5p }\end{array}$ & upregulated & ischemic and idiopathic DCM & {$[72]$} \\
\hline $\begin{array}{l}\text { let-7a-5p, miR-142-3p, miR-145-5p, } \\
\text { miR-454-3p }\end{array}$ & upregulated & $\begin{array}{l}\text { DCM with pathogenic LMNA mutations } \\
\text { compared to idiopathic DCM or controls }\end{array}$ & [73] \\
\hline $\begin{array}{l}\text { let-7a-5p, let-7g-5p, miR-16-2-3p, } \\
\text { miR-210-3p, miR-215-5p, miR-629-5p }\end{array}$ & upregulated & in familiar DCM compared to no familiar & [74] \\
\hline $\begin{array}{l}\text { miR-154-5p, miR-182-5p, miR-1249-ep, } \\
\text { miR-3191-3p, miR-6769b-3p, miR-6855-5p }\end{array}$ & upregulated & $\begin{array}{l}\text { in DCM patients BAG3+ mutation carriers } \\
\text { compared to BAG3 wt }\end{array}$ & {$[75]$} \\
\hline miR-133a & upregulated & $\begin{array}{l}\text { increased expression in LVRR compared to } \\
\text { non-LVRR }\end{array}$ & [76] \\
\hline miR-130b-3p, miR-150-5p, miR-210-3p & upregulated & $\begin{array}{l}\text { distinguish DCM with severe reduced } \\
\text { systolic ejection fraction from moderately } \\
\text { reduced ejection fraction }\end{array}$ & {$[77]$} \\
\hline \multicolumn{4}{|c|}{ Cardiac miRNAs } \\
\hline $\mathrm{miR}-214$ & downregulated & & \multirow{2}{*}[36]{} \\
\hline miR-21 & upregulated & & \\
\hline let-7i, miR-126,miR-155 & downregulated & $\begin{array}{l}\text { let-7i associated with a poor } \\
\text { clinical outcome }\end{array}$ & \multirow[t]{2}{*}{ [78] } \\
\hline $\operatorname{miR}-21$ & upregulated & & \\
\hline miR-21 & upregulated & & [79] \\
\hline miR-223, miR-650 & downregulated & lower in non diabetic DCM than in controls & \multirow{3}{*}{ [80] } \\
\hline miR-216a & upregulated & $\begin{array}{l}\text { higher in both DCM groups than } \\
\text { in controls }\end{array}$ & \\
\hline miR-34b, miR-34c, miR-199b, miR-210 & upregulated & higher in diabetic DCM than in controls & \\
\hline miR-133a & upregulated & $\begin{array}{l}\text { inflammatory DCM without fibrosis vs. } \\
\text { fibrotic DCM }\end{array}$ & [81] \\
\hline miR-378, miR-1, miR-7, miR-29b & downregulated & & \multirow[b]{2}{*}{ [82] } \\
\hline $\begin{array}{l}\text { miR-342, miR-214, miR-125b, miR-145, } \\
\text { miR-181b }\end{array}$ & upregulated & in end-stage heart failure DCM & \\
\hline miR-133 & downregulated & & \multirow{2}{*}{ [83] } \\
\hline miR-21, miR-29 & upregulated & in left, right ventricle and apex & \\
\hline
\end{tabular}


Table 3. Cont.

\begin{tabular}{cccc}
\hline & miRNAs in DCM & Circulating miRNAs & Notes \\
\hline miRNAs & Quantitative Effect & Reference \\
\hline miR-208b & upregulated & $\begin{array}{c}\text { high in DCM with severe heart failure and } \\
\text { subjects with heart failure due to ischemic } \\
\text { heart disease or myocarditis }\end{array}$ \\
\hline miR-26, miR-133a & down & \\
\hline miR-29 & upregulated & \\
\hline
\end{tabular}

Table 4. Summary of miRNAs potentially involved in pediatric DCM.

\begin{tabular}{|c|c|c|c|}
\hline \multicolumn{4}{|c|}{ miRNAs in Pediatric DCM } \\
\hline miRNAs & Quantitative Effect & Notes & Reference \\
\hline \multicolumn{4}{|c|}{ Circulating miRNAs } \\
\hline miR-155, miR-636 & upregulated & $\begin{array}{l}\text { in subjects with poor prognosis } \\
\text { compared to recovered } \\
\text { ventricular function }\end{array}$ & \multirow[t]{2}{*}[86]{} \\
\hline miR-646, miR-639 & downregulated & & \\
\hline miR-454, miR-518f & upregulated & & \multirow[b]{2}{*}{ [87] } \\
\hline $\begin{array}{l}\text { miR-99b, miR-147, miR-155, miR-194, miR-205, } \\
\text { miR-218 miR-302a, miR-544, miR-618, miR-875-3p }\end{array}$ & downregulated & & \\
\hline $\begin{array}{c}\text { let-7f-5p, let-7g-5p, miR-26a-5p, miR-27a-3p, } \\
\text { miR-27b-3p, miR-126-3p, miR-142-5p, miR-143-3p }\end{array}$ & upregulated & & [88] \\
\hline \multicolumn{4}{|c|}{ Cardiac miRNAs } \\
\hline miR-29 family & downregulated & $\begin{array}{l}\text { in cardiac tissue of heart failure } \\
\text { patients without fibrosis }\end{array}$ & [89] \\
\hline
\end{tabular}

\section{Discussion}

miRNAs are biomolecules involved in many cardiovascular diseases, comprised of structural cardiomyopathies potentially involved in sudden cardiac death events. Identifying miRNAs that can be used as reliable biomarkers for the prevention and treatment of structural cardiomyopathies is an interesting challenge.

With recent advances in precision medicine, miRNAs that are differentially expressed in cardiac diseases could be considered potential markers

However, circulating miRNAs are more desirable to use as biomarkers in routine diagnosis because they are easily accessible compared to cardiac tissue miRNAs.

In fact, the complexity of sampling cardiac tissue represents a relevant limit. A possible solution of miRNA tissue analysis could be its evaluation in other biological samples. A promising candidate is represented by urine, as suggested by Cheng et al. in a study conducted on rat model of acute myocardial infarction (AMI). The authors found increased levels of heart-released miR-1 and miR-208 in urine samples after AMI [90]. High levels of cardiac-specific miR-1 were also confirmed by Duan et al. in the urine of ST elevation acute myocardial infarction (STEMI) patients compared to controls [91].

Furthermore, heart tissue miRNAs could be targets of cardiovascular drugs.

Studies conducted in animal models show that pharmacological treatments modulate miRNAs expression. 
Zhao et al. analyzed the heart tissues of a cardiac hypertrophy mouse model and demonstrated that choline administration inhibited pathological cardiac hypertrophy, correcting miR-133a downregulation [92].

Tu et al. found instead that atorvastatin inhibited cardiomyocyte hypertrophy in rats, downregulating miR-22 and consequently modulating the activity of PTEN [93].

Additional research is needed to identify and validate miRNAs as diagnostic biomarkers.

Few studies have been conducted on miRNAs and humans affected by these cardiac diseases, and what emerges is that common results between studies are rare. The differences between studies could be due to different issues, such as a different number of samples/patients analyzed, the sampling time, miRNA quantification, and data normalization. The use of common operating procedures could reduce interstudy variability.

However, three miRNAs (miR-21, miR-29, and miR-133) are frequently reported as being deregulated in the analyzed studies, particularly in reports concerning human HCM and DCM. miR-21, miR-29, and miR-133 seem to be involved in the regulation of cardiac hypertrophy and fibrosis.

miR-21 plays a key role in the cardiovascular system regulating cardiac fibrosis. Cardiac stress can determine miR-21 upregulation and activation of ERK/MAPK pathway in cardiac fibroblasts, resulting in fibrosis, cardiac remodeling, and dysfunction [94].

High levels of miR-21 could contribute to fibrosis progression and fibroblast activation in myocardial infarction targeting molecules as PTEN [95-97], Smad7 [98], and TGF- $\beta$ receptor III [99].

Low levels of miR-21 can inhibit fibrotic tissue proliferation in fibroblasts, potentially acting on ERK/MAPK signaling and CADM1 (Cell Adhesion Molecule 1) $[95,100]$.

miR-29, highly expressed in cardiac fibroblasts, is another miRNA involved in fibrosis regulation. It prevents abnormal collagen expression targeting proteins implicated in fibrogenesis such as fibrillins (FBN1), elastin, and multiple collagens (COL1A1, COL1A2, COL3A1) [101,102].

In mouse model, miR-29 inhibits the fibrogenic differentiation of myoblasts into myofibroblasts [103]. Besides, miR-29 addition determined fibrosis decreasing in hypertension [104].

miR-29 could also be involved in the control of cardiac hypertrophy but with contrasting results. A cell model of cardiac hypertrophy and heart failure showed that miR-29 overexpression inhibits cardiomyocyte hypertrophy via inhibiting NFATc4 expression [105]. In contrast, a mouse model of chronic cardiac pressure overload showed that miR-29 deletion inhibits cardiac hypertrophy and fibrosis; miR-29 seems to act, in part, on Wnt signaling pathway inhibiting several cascade factors in cardiomyocytes [106].

miR-133, the third most reported miRNA, is specifically expressed in skeletal muscle, myocardium and cardiac fibroblasts and is involved in myocyte differentiation and cardiac hypertrophy control [107-109]. miR-133 can regulate cardiac hypertrophy, both in vivo and in vitro, targeting different genes such as, for example, the $\beta$-adrenergic receptor [110], or the hypertrophy-associated mediator NFATc4 [111]. miR-133 overexpression inhibits cardiac hypertrophy while miR-133 suppression induces cardiomyocyte size increasing, without any hypertrophic stimulus [112,113]. miR-133 is also involved in cardiac fibrosis control, regulating the expression of TGF- $\beta 1$ and TGF- $\beta$ receptor type II in vivo and in vitro [114]. TGF- $\beta$ induces CTGF (connective tissue growth factor) expression in connective tissue, controlling collagen production and finally fibrosis. Increased CTGF levels are related to miR-133 low levels while miR-133 overexpression correlates with decreased CTGF levels and also a diminished production of collagens [115].

Despite differences between studies, it is clear that miRNAs are potentially involved in structural inherited cardiomyopathies development and that it is necessary to elucidate the exact role in this context.

Studies conducted on deregulated miRNAs in cardiomyopathies suggest evaluating miRNAs as a potential therapy in treatment of structural cardiac diseases. 
Therapy based on the use of miRNAs involves the modulation of miRNAs expression, i.e., using oligonucleotides that mimic miRNA sequence or using miRNAs inhibitors (anti-miR or antago-miR, synthetic antagonists of miRNAs, used for microRNA silencing). miRNA mimics, which are double-stranded oligonucleotides including the mature miRNA sequence and the complementary passenger strand, can be used to restore low miRNA levels [116].

Anti-miRs are instead chemically modified oligonucleotides that bind single-stranded mature miRNAs, preventing target mRNAs binding [116,117].

miRNA mimics and anti-miRs function as therapeutics have been evaluated in animal model of structural cardiomyopathies. For example, the application of miR-302-367 mimics in the mouse model leads to decreased fibrosis, cardiomyocyte proliferation, mass, and improved function after injury [118].

Caré et al. used a miR-133 antagomiR in mice model, resulting in repression of the HCM phenotype [112]. A study conducted on a heart failure HF mice model induced by pressure overload showed inhibition of cardiomyocyte hypertrophy using anti-miR-21 and anti-miR-132 [94]. The reduction of cardiac hypertrophy is observed also in mouse model treated with anti-miR-132 and anti-miR-652 [119,120]. The results obtained in animal model also suggest a possible future evaluation of miRNAs as therapeutics in human cohorts.

\section{Concluding Remarks}

Since their discovery in 1993, miRNAs have been recognized as important members of all biological pathways. During the last few years, miRNA profiling has become an interesting diagnostic research tool, including in the cardiovascular field. miRNAs' specificity, the possibility of their being co-extracted with DNA, their stability and low susceptibility to degradation are characteristics that make miRNAs ideal biomarkers to be analyzed in clinics.

Our review summarizes the latest news on miRNAs analyzed in human samples of the three most common structural cardiomyopathies. Unfortunately, few miRNAs are in common between the analyzed studies. The diverse results between studies could be related to differences in study design (i.e., sampling mode, extraction methods or quantification) and a possible solution could be the use of standardized protocols.

Research in human samples is in its early stages and further investigations are needed to find common miRNAs to be adopted as validated biomolecules in routine diagnosis, and also to characterize a particular structural cardiomyopathy, to distinguish between cardiomyopathies or phenocopies.

Author Contributions: All authors contributed to writing the manuscript. All authors have read and agreed to the published version of the manuscript.

Funding: This research received no external funding.

Conflicts of Interest: The authors declare no conflict of interest.

\section{References}

1. McKenna, W.J.; Judge, D.P. Epidemiology of the Inherited Cardiomyopathies. Nat. Rev. Cardiol. 2021, 18, 22-36. [CrossRef]

2. Magi, S.; Lariccia, V.; Maiolino, M.; Amoroso, S.; Gratteri, S. Sudden Cardiac Death: Focus on the Genetics of Channelopathies and Cardiomyopathies. J. Biomed. Sci. 2017, 24, 1-18. [CrossRef]

3. Towbin, J.A. Inherited Cardiomyopathies. Circ. J. 2014, 78, 2347-2356. [CrossRef]

4. Miles, C.; Fanton, Z.; Tome, M.; Behr, E.R. Inherited cardiomyopathies. BMJ 2019, 365, 11570. [CrossRef]

5. Latronico, M.V.G.; Catalucci, D.; Condorelli, G. MicroRNA and Cardiac Pathologies. Physiol. Genom. 2008, 34, 239-242. [CrossRef] [PubMed]

6. Latronico, M.V.G.; Condorelli, G. MicroRNAs in Hypertrophy and Heart Failure. Exp. Biol. Med. 2011, 236, 125-131. [CrossRef] [PubMed]

7. Fazmin, I.T.; Achercouk, Z.; Edling, C.E.; Said, A.; Jeevaratnam, K. Circulating MicroRNA as a Biomarker for Coronary Artery Disease. Biomolecules 2020, 10, 1354. [CrossRef] [PubMed]

8. Wronska, A.; Kurkowska-Jastrzebska, I.; Santulli, G. Application of MicroRNAs in Diagnosis and Treatment of Cardiovascular Disease. Acta Physiol. 2015, 213, 60-83. [CrossRef] 
9. Goren, Y.; Meiri, E.; Hogan, C.; Mitchell, H.; Lebanony, D.; Salman, N.; Schliamser, J.E.; Amir, O. Relation of Reduced Expression of MiR-150 in Platelets to Atrial Fibrillation in Patients with Chronic Systolic Heart Failure. Am. J. Cardiol. 2014, 113, 976-981. [CrossRef]

10. Jeon, Y.J.; Kim, O.J.; Kim, S.Y.; Oh, S.H.; Oh, D.; Kim, O.J.; Shin, B.S.; Kim, N.K. Association of the MiR-146a, MiR-149, MiR-196a2, and MiR-499 Polymorphisms with Ischemic Stroke and Silent Brain Infarction Risk. Arterioscler. Thromb. Vasc. Biol. 2013, 33, 420-430. [CrossRef]

11. Bartel, D.P. MicroRNAs: Genomics, Biogenesis, Mechanism, and Function. Cell 2004, 116, 281-297. [CrossRef]

12. Sohel, M.H. Extracellular/Circulating MicroRNAs: Release Mechanisms, Functions and Challenges. Achiev. Life Sci. 2016, 10, 175-186. [CrossRef]

13. Layne, T.R.; Green, R.A.; Lewis, C.A.; Nogales, F.; Dawson Cruz, T.C.; Zehner, Z.E.; Seashols-Williams, S.J. MicroRNA Detection in Blood, Urine, Semen, and Saliva Stains After Compromising Treatments. J. Forensic Sci. 2019, 64, 1831-1837. [CrossRef] [PubMed]

14. Mayes, C.; Houston, R.; Seashols-Williams, S.; LaRue, B.; Hughes-Stamm, S. The Stability and Persistence of Blood and Semen MRNA and MiRNA Targets for Body Fluid Identification in Environmentally Challenged and Laundered Samples. Leg. Med. 2019, 38, 45-50. [CrossRef]

15. Mocellin, S.; Pasquali, S.; Pilati, P. Oncomirs: From Tumor Biology to Molecularly Targeted Anticancer Strategies. Mini Rev. Med. Chem. 2009, 9, 70-80. [CrossRef] [PubMed]

16. Iqbal, J.; Al Qarni, A.; Hawwari, A.; Alghanem, A.F.; Ahmed, G. Metabolic Syndrome, Dyslipidemia and Regulation of Lipoprotein Metabolism. Curr. Diabetes Rev. 2018, 14, 427-433. [CrossRef] [PubMed]

17. van den Berg, M.M.J.; Krauskopf, J.; Ramaekers, J.G.; Kleinjans, J.C.S.; Prickaerts, J.; Briedé, J.J. Circulating MicroRNAs as Potential Biomarkers for Psychiatric and Neurodegenerative Disorders. Prog. Neurobiol. 2020, 185, 101732. [CrossRef]

18. Marian, A.J.; Braunwald, E. Hypertrophic Cardiomyopathy: Genetics, Pathogenesis, Clinical Manifestations, Diagnosis, and Therapy. Circ. Res. 2017, 121, 749-770. [CrossRef]

19. Elliott, P.M.; Anastasakis, A.; Borger, M.A.; Borggrefe, M.; Cecchi, F.; Charron, P.; Hagege, A.A.; Lafont, A.; Limongelli, G.; Mahrholdt, H.; et al. 2014 ESC Guidelines on Diagnosis and Management of Hypertrophic Cardiomyopathy: The Task Force for the Diagnosis and Management of Hypertrophic Cardiomyopathy of the European Society of Cardiology (ESC). Eur. Heart J. 2014, 35, 2733-2779. [CrossRef] [PubMed]

20. Aquaro, G.D.; Guidi, B.; Biondi, F.; Chiti, E.; Santurro, A.; Scopetti, M.; Turillazzi, E.; Di Paolo, M. Post-Mortem Cardiac Magnetic Resonance for the Diagnosis of Hypertrophic Cardiomyopathy. Diagnostics 2020, 10, 981. [CrossRef]

21. Pradella, S.; Grazzini, G.; De Amicis, C.; Letteriello, M.; Acquafresca, M.; Miele, V. Cardiac Magnetic Resonance in Hypertrophic and Dilated Cardiomyopathies. Radiol. Med. 2020, 125, 1056-1071. [CrossRef] [PubMed]

22. Sabater-Molina, M.; Pérez-Sánchez, I.; Hernández Del Rincón, J.P.; Gimeno, J.R. Genetics of Hypertrophic Cardiomyopathy: A Review of Current State. Clin. Genet. 2018, 93, 3-14. [CrossRef]

23. Medical Masterclass contributors; Firth, J. Cardiology: Hypertrophic Cardiomyopathy. Clin. Med. 2019, 19, 61-63. [CrossRef]

24. Roncarati, R.; Viviani Anselmi, C.; Losi, M.A.; Papa, L.; Cavarretta, E.; Da Costa Martins, P.; Contaldi, C.; Saccani Jotti, G.; Franzone, A.; Galastri, L.; et al. Circulating MiR-29a, among Other up-Regulated MicroRNAs, Is the Only Biomarker for Both Hypertrophy and Fibrosis in Patients with Hypertrophic Cardiomyopathy. J. Am. Coll. Cardiol. 2014, 63, 920-927. [CrossRef]

25. Fang, L.; Ellims, A.H.; Moore, X.; White, D.A.; Taylor, A.J.; Chin-Dusting, J.; Dart, A.M. Circulating MicroRNAs as Biomarkers for Diffuse Myocardial Fibrosis in Patients with Hypertrophic Cardiomyopathy. J. Transl. Med. 2015, 13, 1-12. [CrossRef] [PubMed]

26. Derda, A.A.; Thum, S.; Lorenzen, J.M.; Bavendiek, U.; Heineke, J.; Keyser, B.; Stuhrmann, M.; Givens, R.C.; Kennel, P.J.; Schulze, P.C.; et al. Blood-Based MicroRNA Signatures Differentiate Various Forms of Cardiac Hypertrophy. Int. J. Cardiol. 2015, 196, 115-122. [CrossRef] [PubMed]

27. Zhou, J.; Zhou, Y.; Wang, C.-X. LncRNA-MIAT Regulates Fibrosis in Hypertrophic Cardiomyopathy (HCM) by Mediating the Expression of MiR-29a-3p. J. Cell Biochem. 2018, 120, 7265-7275. [CrossRef]

28. Gudkova, A.Y.; Davidova, V.G.; Bezhanishvili, T.G.; Pyko, S.A.; Zarayskiy, M.I. Characterisation of circulating microRNA-21 levels in patients with hypertrophic cardiomyopathy. Ter. Arkh. 2020, 92, 51-56. [CrossRef] [PubMed]

29. Palacín, M.; Reguero, J.R.; Martín, M.; Díaz Molina, B.; Morís, C.; Alvarez, V.; Coto, E. Profile of MicroRNAs Differentially Produced in Hearts from Patients with Hypertrophic Cardiomyopathy and Sarcomeric Mutations. Clin. Chem. 2011, 57, $1614-1616$. [CrossRef] [PubMed]

30. Wang, C.; Wang, S.; Zhao, P.; Wang, X.; Wang, J.; Wang, Y.; Song, L.; Zou, Y.; Hui, R. MiR-221 Promotes Cardiac Hypertrophy in Vitro through the Modulation of P27 Expression. J. Cell Biochem. 2012, 113, 2040-2046. [CrossRef]

31. Leptidis, S.; El Azzouzi, H.; Lok, S.I.; de Weger, R.; Olieslagers, S.; Olieslagers, S.; Kisters, N.; Silva, G.J.; Heymans, S.; Cuppen, E.; et al. A Deep Sequencing Approach to Uncover the MiRNOME in the Human Heart. PLoS ONE 2013, 8, e57800. [CrossRef]

32. Liu, Y.; Afzal, J.; Vakrou, S.; Greenland, G.V.; Talbot, C.C.; Hebl, V.B.; Guan, Y.; Karmali, R.; Tardiff, J.C.; Leinwand, L.A.; et al. Differences in MicroRNA-29 and Pro-Fibrotic Gene Expression in Mouse and Human Hypertrophic Cardiomyopathy. Front. Cardiovasc. Med. 2019, 6, 170. [CrossRef]

33. Kuster, D.W.D.; Mulders, J.; Ten Cate, F.J.; Michels, M.; Dos Remedios, C.G.; da Costa Martins, P.A.; van der Velden, J.; Oudejans, C.B.M. MicroRNA Transcriptome Profiling in Cardiac Tissue of Hypertrophic Cardiomyopathy Patients with MYBPC3 Mutations. J. Mol. Cell Cardiol. 2013, 65, 59-66. [CrossRef] 
34. Song, L.; Su, M.; Wang, S.; Zou, Y.; Wang, X.; Wang, Y.; Cui, H.; Zhao, P.; Hui, R.; Wang, J. MiR-451 Is Decreased in Hypertrophic Cardiomyopathy and Regulates Autophagy by Targeting TSC1. J. Cell Mol. Med. 2014, 18, 2266-2274. [CrossRef]

35. Ming, S.; Shui-Yun, W.; Wei, Q.; Jian-Hui, L.; Ru-Tai, H.; Lei, S.; Mei, J.; Hui, W.; Ji-Zheng, W. MiR-139-5p Inhibits IsoproterenolInduced Cardiac Hypertrophy by Targetting c-Jun. Biosci. Rep. 2018, 38, BSR20171430. [CrossRef]

36. Li, M.; Chen, X.; Chen, L.; Chen, K.; Zhou, J.; Song, J. MiR-1-3p That Correlates with Left Ventricular Function of HCM Can Serve as a Potential Target and Differentiate HCM from DCM. J. Transl. Med. 2018, 16, 1-10. [CrossRef] [PubMed]

37. Sun, D.; Li, C.; Liu, J.; Wang, Z.; Liu, Y.; Luo, C.; Chen, Y.; Wen, S. Expression Profile of MicroRNAs in Hypertrophic Cardiomyopathy and Effects of MicroRNA-20 in Inducing Cardiomyocyte Hypertrophy Through Regulating Gene MFN2. DNA Cell Biol. 2019, 38, 796-807. [CrossRef] [PubMed]

38. Huang, D.; Chen, Z.; Wang, J.; Chen, Y.; Liu, D.; Lin, K. MicroRNA-221 Is a Potential Biomarker of Myocardial Hypertrophy and Fibrosis in Hypertrophic Obstructive Cardiomyopathy. Biosci. Rep. 2020, 40, BSR20191234. [CrossRef] [PubMed]

39. Cammarata, G.; Scalia, S.; Colomba, P.; Zizzo, C.; Pisani, A.; Riccio, E.; Montalbano, M.; Alessandro, R.; Giordano, A.; Duro, G. A Pilot Study of Circulating MicroRNAs as Potential Biomarkers of Fabry Disease. Oncotarget 2018, 9, 27333-27345. [CrossRef]

40. Xiao, K.; Lu, D.; Hoepfner, J.; Santer, L.; Gupta, S.; Pfanne, A.; Thum, S.; Lenders, M.; Brand, E.; Nordbeck, P.; et al. Circulating MicroRNAs in Fabry Disease. Sci. Rep. 2019, 9, 1-10. [CrossRef]

41. Derda, A.A.; Pfanne, A.; Bär, C.; Schimmel, K.; Kennel, P.J.; Xiao, K.; Schulze, P.C.; Bauersachs, J.; Thum, T. Blood-Based MicroRNA Profiling in Patients with Cardiac Amyloidosis. PLoS ONE 2018, 13, e0204235. [CrossRef]

42. Tarallo, A.; Carissimo, A.; Gatto, F.; Nusco, E.; Toscano, A.; Musumeci, O.; Coletta, M.; Karali, M.; Acampora, E.; Damiano, C.; et al. MicroRNAs as Biomarkers in Pompe Disease. Genet. Med. 2019, 21, 591-600. [CrossRef]

43. Sen-Chowdhry, S.; Syrris, P.; Prasad, S.K.; Hughes, S.E.; Merrifield, R.; Ward, D.; Pennell, D.J.; McKenna, W.J. Left-Dominant Arrhythmogenic Cardiomyopathy: An under-Recognized Clinical Entity. J. Am. Coll Cardiol. 2008, 52, 2175-2187. [CrossRef] [PubMed]

44. Saguner, A.M.; Brunckhorst, C.; Duru, F. Arrhythmogenic Ventricular Cardiomyopathy: A Paradigm Shift from Right to Biventricular Disease. World J. Cardiol. 2014, 6, 154-174. [CrossRef] [PubMed]

45. Stadiotti, I.; Catto, V.; Casella, M.; Tondo, C.; Pompilio, G.; Sommariva, E. Arrhythmogenic Cardiomyopathy: The Guilty Party in Adipogenesis. J. Cardiovasc. Transl. Res. 2017, 10, 446-454. [CrossRef] [PubMed]

46. Thiene, G.; Nava, A.; Corrado, D.; Rossi, L.; Pennelli, N. Right Ventricular Cardiomyopathy and Sudden Death in Young People. N. Engl. J. Med. 1988, 318, 129-133. [CrossRef]

47. Marcus Frank, I.; McKenna William, J.; Sherrill, D.; Basso, C.; Bauce, B.; Bluemke David, A.; Calkins, H.; Corrado, D.; Cox Moniek, G.P.J.; Daubert James, P.; et al. Diagnosis of Arrhythmogenic Right Ventricular Cardiomyopathy/Dysplasia. Circulation 2010, 121, 1533-1541. [CrossRef] [PubMed]

48. Castaños Gutiérrez, S.L.; Kamel, I.R.; Zimmerman, S.L. Current Concepts on Diagnosis and Prognosis of Arrhythmogenic Right Ventricular Cardiomyopathy /Dysplasia. J. Thorac. Imaging 2016, 31, 324-335. [CrossRef]

49. Bennett, R.G.; Haqqani, H.M.; Berruezo, A.; Della Bella, P.; Marchlinski, F.E.; Hsu, C.-J.; Kumar, S. Arrhythmogenic Cardiomyopathy in 2018-2019: ARVC/ALVC or Both? Heart Lung. Circ. 2019, 28, 164-177. [CrossRef] [PubMed]

50. Calore, M.; Lorenzon, A.; De Bortoli, M.; Poloni, G.; Rampazzo, A. Arrhythmogenic Cardiomyopathy: A Disease of Intercalated Discs. Cell Tissue Res. 2015, 360, 491-500. [CrossRef] [PubMed]

51. Sommariva, E.; D’Alessandra, Y.; Farina, F.M.; Casella, M.; Cattaneo, F.; Catto, V.; Chiesa, M.; Stadiotti, I.; Brambilla, S.; Dello Russo, A.; et al. MiR-320a as a Potential Novel Circulating Biomarker of Arrhythmogenic CardioMyopathy. Sci. Rep. 2017, 7, 1-10. [CrossRef] [PubMed]

52. Yamada, S.; Hsiao, Y.-W.; Chang, S.-L.; Lin, Y.-J.; Lo, L.-W.; Chung, F.-P.; Chiang, S.-J.; Hu, Y.-F.; Tuan, T.-C.; Chao, T.-F.; et al. Circulating MicroRNAs in Arrhythmogenic Right Ventricular Cardiomyopathy with Ventricular Arrhythmia. Europace 2018, 20, f37-f45. [CrossRef]

53. Bueno Marinas, M.; Celeghin, R.; Cason, M.; Bariani, R.; Frigo, A.C.; Jager, J.; Syrris, P.; Elliott, P.M.; Bauce, B.; Thiene, G.; et al. A MicroRNA Expression Profile as Non-Invasive Biomarker in a Large Arrhythmogenic Cardiomyopathy Cohort. Int. J. Mol. Sci. 2020, 21, 1536. [CrossRef]

54. Zhang, H.; Liu, S.; Dong, T.; Yang, J.; Xie, Y.; Wu, Y.; Kang, K.; Hu, S.; Gou, D.; Wei, Y. Profiling of Differentially Expressed MicroRNAs in Arrhythmogenic Right Ventricular Cardiomyopathy. Sci. Rep. 2016, 6, 1-11. [CrossRef] [PubMed]

55. Rainer, J.; Meraviglia, V.; Blankenburg, H.; Piubelli, C.; Pramstaller, P.P.; Paolin, A.; Cogliati, E.; Pompilio, G.; Sommariva, E.; Domingues, F.S.; et al. The Arrhythmogenic Cardiomyopathy-Specific Coding and Non-Coding Transcriptome in Human Cardiac Stromal Cells. BMC Genom. 2018, 19, 1-12. [CrossRef] [PubMed]

56. Weintraub, R.G.; Semsarian, C.; Macdonald, P. Dilated Cardiomyopathy. Lancet 2017, 390, 400-414. [CrossRef]

57. Japp, A.G.; Gulati, A.; Cook, S.A.; Cowie, M.R.; Prasad, S.K. The Diagnosis and Evaluation of Dilated Cardiomyopathy. J. Am. Coll Cardiol. 2016, 67, 2996-3010. [CrossRef]

58. Jefferies, J.L.; Towbin, J.A. Dilated Cardiomyopathy. Lancet 2010, 375, 752-762. [CrossRef]

59. Pérez-Serra, A.; Toro, R.; Sarquella-Brugada, G.; de Gonzalo-Calvo, D.; Cesar, S.; Carro, E.; Llorente-Cortes, V.; Iglesias, A.; Brugada, J.; Brugada, R.; et al. Genetic Basis of Dilated Cardiomyopathy. Int. J. Cardiol. 2016, 224, 461-472. [CrossRef]

60. Schultheiss, H.-P.; Fairweather, D.; Caforio, A.L.P.; Escher, F.; Hershberger, R.E.; Lipshultz, S.E.; Liu, P.P.; Matsumori, A.; Mazzanti, A.; McMurray, J.; et al. Dilated Cardiomyopathy. Nat. Rev. Dis. Primers 2019, 5, 1-19. [CrossRef] 
61. Pinto, Y.M.; Elliott, P.M.; Arbustini, E.; Adler, Y.; Anastasakis, A.; Böhm, M.; Duboc, D.; Gimeno, J.; de Groote, P.; Imazio, M.; et al. Proposal for a Revised Definition of Dilated Cardiomyopathy, Hypokinetic Non-Dilated Cardiomyopathy, and Its Implications for Clinical Practice: A Position Statement of the ESC Working Group on Myocardial and Pericardial Diseases. Eur. Heart J. 2016, 37, 1850-1858. [CrossRef]

62. Taylor, M.R.; Carniel, E.; Mestroni, L. Cardiomyopathy, Familial Dilated. Orphanet. J. Rare Dis. 2006, 1, 1-8. [CrossRef]

63. Francone, M. Role of Cardiac Magnetic Resonance in the Evaluation of Dilated Cardiomyopathy: Diagnostic Contribution and Prognostic Significance. ISRN Radiol. 2014, 2014, 365404. [CrossRef] [PubMed]

64. Priori, S.G.; Blomström-Lundqvist, C.; Mazzanti, A.; Blom, N.; Borggrefe, M.; Camm, J.; Elliott, P.M.; Fitzsimons, D.; Hatala, R.; Hindricks, G.; et al. 2015 ESC Guidelines for the Management of Patients with Ventricular Arrhythmias and the Prevention of Sudden Cardiac Death: The Task Force for the Management of Patients with Ventricular Arrhythmias and the Prevention of Sudden Cardiac Death of the European Society of Cardiology (ESC)Endorsed by: Association for European Paediatric and Congenital Cardiology (AEPC). Eur. Heart J. 2015, 36, 2793-2867. [CrossRef] [PubMed]

65. Nair, N.; Kumar, S.; Gongora, E.; Gupta, S. Circulating MiRNA as Novel Markers for Diastolic Dysfunction. Mol. Cell Biochem. 2013, 376, 33-40. [CrossRef] [PubMed]

66. Gupta, M.K.; Halley, C.; Duan, Z.H.; Lappe, J.; Viterna, J.; Jana, S.; Augoff, K.; Mohan, M.L.; Vasudevan, N.T.; Na, J.; et al. MiRNA-548c: A Specific Signature in Circulating PBMCs from Dilated Cardiomyopathy Patients. J. Mol. Cell. Cardiol. 2013, 62, 131-141. [CrossRef] [PubMed]

67. Fan, K.-L.; Zhang, H.-F.; Shen, J.; Zhang, Q.; Li, X.-L. Circulating MicroRNAs Levels in Chinese Heart Failure Patients Caused by Dilated Cardiomyopathy. Indian Heart J. 2013, 65, 12-16. [CrossRef] [PubMed]

68. Yu, M.; Liang, W.; Xie, Y.; Long, Q.; Cheng, X.; Liao, Y.-H.; Yuan, J. Circulating MiR-185 Might Be a Novel Biomarker for Clinical Outcome in Patients with Dilated Cardiomyopathy. Sci. Rep. 2016, 6, 1-10. [CrossRef]

69. Wang, H.; Chen, F.; Tong, J.; Li, Y.; Cai, J.; Wang, Y.; Li, P.; Hao, Y.; Tian, W.; Lv, Y.; et al. Circulating MicroRNAs as Novel Biomarkers for Dilated Cardiomyopathy. Cardiol. J. 2017, 24, 65-73. [CrossRef]

70. Rubiś, P.; Totoń-Żurańska, J.; Wiśniowska-Śmiałek, S.; Holcman, K.; Kołton-Wróż, M.; Wołkow, P.; Wypasek, E.; Natorska, J.; Rudnicka-Sosin, L.; Pawlak, A.; et al. Relations between Circulating MicroRNAs (MiR-21, MiR-26, MiR-29, MiR-30 and MiR-133a), Extracellular Matrix Fibrosis and Serum Markers of Fibrosis in Dilated Cardiomyopathy. Int. J. Cardiol. 2017, 231, 201-206. [CrossRef]

71. Wu, T.; Chen, Y.; Du, Y.; Tao, J.; Zhou, Z.; Yang, Z. Serum Exosomal MiR-92b-5p as a Potential Biomarker for Acute Heart Failure Caused by Dilated Cardiomyopathy. Cell Physiol. Biochem. 2018, 46, 1939-1950. [CrossRef] [PubMed]

72. Onrat, S.T.; Onrat, E.; Ercan Onay, E.; Yalım, Z.; Avşar, A. The Genetic Determination of the Differentiation Between Ischemic Dilated Cardiomyopathy and Idiopathic Dilated Cardiomyopathy. Genet. Test. Mol. Biomark. 2018, 22, 644-651. [CrossRef]

73. Toro, R.; Blasco-Turrión, S.; Morales-Ponce, F.J.; Gonzalez, P.; Martínez-Camblor, P.; López-Granados, A.; Brugada, R.; Campuzano, O.; Pérez-Serra, A.; Rosa Longobardo, F.; et al. Plasma MicroRNAs as Biomarkers for Lamin A/C-Related Dilated Cardiomyopathy. J. Mol. Med. (Berl) 2018, 96, 845-856. [CrossRef] [PubMed]

74. Belmonte, T.; Mangas, A.; Calderon-Dominguez, M.; Quezada-Feijoo, M.; Ramos, M.; Campuzano, O.; Gomez, S.; Peña, M.L.; Cubillos-Arango, A.M.; Dominguez, F.; et al. Peripheral MicroRNA Panels to Guide the Diagnosis of Familial Cardiomyopathy. Transl. Res. 2020, 218, 1-15. [CrossRef]

75. Zaragoza, C.; Saura, M.; Hernández, I.; Ramirez-Carracedo, R.; García-García, F.; Zamorano, J.L.; Mangas, A.; Toro, R. Differential Expression of Circulating MiRNAs as a Novel Tool to Assess BAG3-Associated Familial Dilated Cardiomyopathy. Biosci. Rep. 2019, 39, BSR20180934. [CrossRef] [PubMed]

76. Dziewięcka, E.; Totoń-Żurańska, J.; Wołkow, P.; Kołton-Wróż, M.; Pitera, E.; WiśniowskaŚmiałek, S.; Khachatryan, L.; Karabinowska, A.; Szymonowicz, M.; Podolec, P.; et al. Relations between Circulating and Myocardial Fibrosis-Linked MicroRNAs with Left Ventricular Reverse Remodeling in Dilated Cardiomyopathy. Adv. Clin. Exp. Med. 2020, $29,285-293$. [CrossRef]

77. Calderon-Dominguez, M.; Belmonte, T.; Quezada-Feijoo, M.; Ramos, M.; Calderon-Dominguez, J.; Campuzano, O.; Mangas, A.; Toro, R. Plasma Microrna Expression Profile for Reduced Ejection Fraction in Dilated Cardiomyopathy. Sci. Rep. 2021, 11, 1-15. [CrossRef]

78. Satoh, M.; Minami, Y.; Takahashi, Y.; Tabuchi, T.; Nakamura, M. A Cellular MicroRNA, Let-7i, Is a Novel Biomarker for Clinical Outcome in Patients with Dilated Cardiomyopathy. J. Card. Fail. 2011, 17, 923-929. [CrossRef]

79. Xu, H.-F.; Ding, Y.-J.; Zhang, Z.-X.; Wang, Z.-F.; Luo, C.-L.; Li, B.-X.; Shen, Y.-W.; Tao, L.-Y.; Zhao, Z.-Q. MicroRNA-21 Regulation of the Progression of Viral Myocarditis to Dilated Cardiomyopathy. Mol. Med. Rep. 2014, 10, 161-168. [CrossRef]

80. Greco, S.; Fasanaro, P.; Castelvecchio, S.; D’Alessandra, Y.; Arcelli, D.; Di Donato, M.; Malavazos, A.; Capogrossi, M.C.; Menicanti, L.; Martelli, F. MicroRNA Dysregulation in Diabetic Ischemic Heart Failure Patients. Diabetes 2012, 61, $1633-1641$. [CrossRef]

81. Besler, C.; Urban, D.; Watzka, S.; Lang, D.; Rommel, K.-P.; Kandolf, R.; Klingel, K.; Thiele, H.; Linke, A.; Schuler, G.; et al. Endomyocardial MiR-133a Levels Correlate with Myocardial Inflammation, Improved Left Ventricular Function, and Clinical Outcome in Patients with Inflammatory Cardiomyopathy. Eur. J. Heart Fail. 2016, 18, 1442-1451. [CrossRef] 
82. Naga Prasad, S.V.; Gupta, M.K.; Duan, Z.-H.; Surampudi, V.S.K.; Liu, C.-G.; Kotwal, A.; Moravec, C.S.; Starling, R.C.; Perez, D.M.; Sen, S.; et al. A Unique MicroRNA Profile in End-Stage Heart Failure Indicates Alterations in Specific Cardiovascular Signaling Networks. PLoS ONE 2017, 12, e0170456. [CrossRef]

83. Wang, Y.; Li, M.; Xu, L.; Liu, J.; Wang, D.; Li, Q.; Wang, L.; Li, P.; Chen, S.; Liu, T. Expression of Bcl-2 and MicroRNAs in Cardiac Tissues of Patients with Dilated Cardiomyopathy. Mol. Med. Rep. 2017, 15, 359-365. [CrossRef] [PubMed]

84. Zhou, Q.; Schötterl, S.; Backes, D.; Brunner, E.; Hahn, J.K.; Ionesi, E.; Aidery, P.; Sticht, C.; Labeit, S.; Kandolf, R.; et al. Inhibition of MiR-208b Improves Cardiac Function in Titin-Based Dilated Cardiomyopathy. Int. J. Cardiol. 2017, 230, 634-641. [CrossRef]

85. Rubiś, P.; Toton-Żurańska, J.; Wiśniowska-Śmiałek, S.; Dziewięcka, E.; Kołton-Wróż, M.; Wołkow, P.; Pitera, E.; Rudnicka-Sosin, L.; Garlitski, A.C.; Gackowski, A.; et al. The Relationship between Myocardial Fibrosis and Myocardial MicroRNAs in Dilated Cardiomyopathy: A Link between Mir-133a and Cardiovascular Events. J. Cell Mol. Med. 2018, 22, 2514-2517. [CrossRef] [PubMed]

86. Miyamoto, S.D.; Karimpour-Fard, A.; Peterson, V.; Auerbach, S.R.; Stenmark, K.R.; Stauffer, B.L.; Sucharov, C.C. Circulating MicroRNA as a Biomarker for Recovery in Pediatric Dilated Cardiomyopathy. J. Heart Lung. Transpl. 2015, 34, 724-733. [CrossRef] [PubMed]

87. Enes Coşkun, M.; Kervancıoğlu, M.; Öztuzcu, S.; Yılmaz Coşkun, F.; Ergün, S.; Başpınar, O.; Kılınç, M.; Temel, L.; Coşkun, M.Y. Plasma MicroRNA Profiling of Children with Idiopathic Dilated Cardiomyopathy. Biomarkers 2016, 21, 56-61. [CrossRef]

88. Jiao, M.; You, H.-Z.; Yang, X.-Y.; Yuan, H.; Li, Y.-L.; Liu, W.-X.; Jin, M.; Du, J. Circulating MicroRNA Signature for the Diagnosis of Childhood Dilated Cardiomyopathy. Sci. Rep. 2018, 8, 1-9. [CrossRef] [PubMed]

89. Woulfe, K.C.; Siomos, A.K.; Nguyen, H.; SooHoo, M.; Galambos, C.; Stauffer, B.L.; Sucharov, C.; Miyamoto, S. Fibrosis and Fibrotic Gene Expression in Pediatric and Adult Patients With Idiopathic Dilated Cardiomyopathy. J. Card Fail. 2017, 23, 314-324. [CrossRef]

90. Cheng, Y.; Wang, X.; Yang, J.; Duan, X.; Yao, Y.; Shi, X.; Chen, Z.; Fan, Z.; Liu, X.; Qin, S.; et al. A Translational Study of Urine MiRNAs in Acute Myocardial Infarction. J. Mol. Cell Cardiol. 2012, 53, 668-676. [CrossRef]

91. Duan, X.; Zhou, X.; Wang, X.; Fan, Z.; Zhang, C.; Chen, Z. Urine cardiac specific microRNA-1 level in patients with ST segment elevation acute myocardial infarction. Zhongguo Wei Zhong Bing Ji Jiu Yi Xue 2012, 24, 709-712.

92. Zhao, Y.; Wang, C.; Wu, J.; Wang, Y.; Zhu, W.; Zhang, Y.; Du, Z. Choline Protects against Cardiac Hypertrophy Induced by Increased After-Load. Int. J. Biol. Sci. 2013, 9, 295-302. [CrossRef] [PubMed]

93. Tu, Y.; Wan, L.; Bu, L.; Zhao, D.; Dong, D.; Huang, T.; Cheng, Z.; Shen, B. MicroRNA-22 Downregulation by Atorvastatin in a Mouse Model of Cardiac Hypertrophy: A New Mechanism for Antihypertrophic Intervention. Cell Physiol. Biochem. 2013, 31, 997-1008. [CrossRef]

94. Thum, T.; Gross, C.; Fiedler, J.; Fischer, T.; Kissler, S.; Bussen, M.; Galuppo, P.; Just, S.; Rottbauer, W.; Frantz, S.; et al. MicroRNA-21 Contributes to Myocardial Disease by Stimulating MAP Kinase Signalling in Fibroblasts. Nature 2008, 456, 980-984. [CrossRef]

95. Roy, S.; Khanna, S.; Hussain, S.-R.A.; Biswas, S.; Azad, A.; Rink, C.; Gnyawali, S.; Shilo, S.; Nuovo, G.J.; Sen, C.K. MicroRNA Expression in Response to Murine Myocardial Infarction: MiR-21 Regulates Fibroblast Metalloprotease-2 via Phosphatase and Tensin Homologue. Cardiovasc. Res. 2009, 82, 21-29. [CrossRef] [PubMed]

96. Yang, F.; Liu, W.; Yan, X.; Zhou, H.; Zhang, H.; Liu, J.; Yu, M.; Zhu, X.; Ma, K. Effects of Mir-21 on Cardiac Microvascular Endothelial Cells After Acute Myocardial Infarction in Rats: Role of Phosphatase and Tensin Homolog (PTEN)/Vascular Endothelial Growth Factor (VEGF) Signal Pathway. Med. Sci. Monit. 2016, 22, 3562-3575. [CrossRef]

97. Li, L.; Chen, Q.; Feng, C.; Jin, Y.; Xia, S. Aberrant Expression of TNRC6a and MiR-21 during Myocardial Infarction. 3 Biotech 2019, 9, 1-6. [CrossRef] [PubMed]

98. Yuan, J.; Chen, H.; Ge, D.; Xu, Y.; Xu, H.; Yang, Y.; Gu, M.; Zhou, Y.; Zhu, J.; Ge, T.; et al. Mir-21 Promotes Cardiac Fibrosis After Myocardial Infarction Via Targeting Smad7. Cell Physiol. Biochem. 2017, 42, 2207-2219. [CrossRef]

99. Liang, H.; Zhang, C.; Ban, T.; Liu, Y.; Mei, L.; Piao, X.; Zhao, D.; Lu, Y.; Chu, W.; Yang, B. A Novel Reciprocal Loop between MicroRNA-21 and TGFßRIII Is Involved in Cardiac Fibrosis. Int. J. Biochem. Cell Biol. 2012, 44, 2152-2160. [CrossRef]

100. Cao, W.; Shi, P.; Ge, J.-J. MiR-21 Enhances Cardiac Fibrotic Remodeling and Fibroblast Proliferation via CADM1/STAT3 Pathway. BMC Cardiovasc. Disord. 2017, 17, 1-11. [CrossRef]

101. Kriegel, A.J.; Liu, Y.; Fang, Y.; Ding, X.; Liang, M. The MiR-29 Family: Genomics, Cell Biology, and Relevance to Renal and Cardiovascular Injury. Physiol. Genomics 2012, 44, 237-244. [CrossRef] [PubMed]

102. Dawson, K.; Wakili, R.; Ordög, B.; Clauss, S.; Chen, Y.; Iwasaki, Y.; Voigt, N.; Qi, X.Y.; Sinner, M.F.; Dobrev, D.; et al. MicroRNA29: A Mechanistic Contributor and Potential Biomarker in Atrial Fibrillation. Circulation 2013, 127, 1466-1475. [CrossRef] [PubMed]

103. Zhou, L.; Wang, L.; Lu, L.; Jiang, P.; Sun, H.; Wang, H. Inhibition of MiR-29 by TGF-Beta- Smad3 Signaling through Dual Mechanisms Promotes Transdifferentiation of Mouse Myoblasts into Myofibroblasts. PLoS ONE 2012, 7, e33766. [CrossRef] [PubMed]

104. Zhang, Y.; Huang, X.-R.; Wei, L.-H.; Chung, A.C.; Yu, C.-M.; Lan, H.-Y. MiR-29b as a Therapeutic Agent for Angiotensin II-Induced Cardiac Fibrosis by Targeting TGF- $\beta$ /Smad3 Signaling. Mol. Ther. 2014, 22, 974-985. [CrossRef]

105. Li, M.; Wang, N.; Zhang, J.; He, H.P.; Gong, H.Q.; Zhang, R.; Song, T.F.; Zhang, L.N.; Guo, Z.X.; Cao, D.S.; et al. MicroRNA-29a-3p attenuates ET-1-induced hypertrophic responses in H9c2 cardiomyocytes. Gene 2016, 585, 44-50. [CrossRef] 
106. Sassi, Y.; Avramopoulos, P.; Ramanujam, D.; Grüter, L.; Werfel, S.; Giosele, S.; Brunner, A.-D.; Esfandyari, D.; Papadopoulou, A.S.; De Strooper, B.; et al. Cardiac Myocyte MiR-29 Promotes Pathological Remodeling of the Heart by Activating Wnt Signaling. Nat. Commun. 2017, 8, 1-11. [CrossRef]

107. Rao, P.K.; Kumar, R.M.; Farkhondeh, M.; Baskerville, S.; Lodish, H.F. Myogenic Factors That Regulate Expression of MuscleSpecific MicroRNAs. Proc. Natl. Acad. Sci. USA 2006, 103, 8721-8726. [CrossRef] [PubMed]

108. Townley-Tilson, W.H.D.; Callis, T.E.; Wang, D.-Z. MicroRNAs 1, 133, and 206: Critical Factors of Skeletal and Cardiac Muscle Development, Function, and Disease. Int. J. Biochem. Cell Biol. 2010, 42, 1252-1255. [CrossRef]

109. Kumar Mishra, P. Is Mir-133a a Promising Therapeutic Target for Heart Failure? J. Diabetes Metab. 2014, 5. [CrossRef]

110. Li, Q.; Lin, X.; Yang, X.; Chang, J. NFATc4 Is Negatively Regulated in MiR-133a-Mediated Cardiomyocyte Hypertrophic Repression. Am. J. Physiol. Heart Circ. Physiol. 2010, 298, H1340-H1347. [CrossRef]

111. Sucharov, C.; Bristow, M.R.; Port, J.D. MiRNA Expression in the Failing Human Heart: Functional Correlates. J. Mol. Cell Cardiol. 2008, 45, 185-192. [CrossRef]

112. Carè, A.; Catalucci, D.; Felicetti, F.; Bonci, D.; Addario, A.; Gallo, P.; Bang, M.-L.; Segnalini, P.; Gu, Y.; Dalton, N.D.; et al. MicroRNA-133 Controls Cardiac Hypertrophy. Nat. Med. 2007, 13, 613-618. [CrossRef]

113. Drawnel, F.M.; Wachten, D.; Molkentin, J.D.; Maillet, M.; Aronsen, J.M.; Swift, F.; Sjaastad, I.; Liu, N.; Catalucci, D.; Mikoshiba, K.; et al. Mutual Antagonism between IP3RII and MiRNA-133a Regulates Calcium Signals and Cardiac Hypertrophy. J. Cell Biol. 2012, 199, 783-798. [CrossRef] [PubMed]

114. Shan, H.; Zhang, Y.; Lu, Y.; Zhang, Y.; Pan, Z.; Cai, B.; Wang, N.; Li, X.; Feng, T.; Hong, Y.; et al. Downregulation of MiR-133 and MiR-590 Contributes to Nicotine-Induced Atrial Remodelling in Canines. Cardiovasc. Res. 2009, 83, 465-472. [CrossRef]

115. Duisters, R.F.; Tijsen, A.J.; Schroen, B.; Leenders, J.J.; Lentink, V.; van der Made, I.; Herias, V.; van Leeuwen, R.E.; Schellings, M.W.; Barenbrug, P.; et al. MiR-133 and MiR-30 Regulate Connective Tissue Growth Factor: Implications for a Role of MicroRNAs in Myocardial Matrix Remodeling. Circ. Res. 2009, 104, 170-178. [CrossRef] [PubMed]

116. Lu, T.X.; Rothenberg, M.E. MicroRNA. J. Allergy Clin. Immunol. 2018, 141, 1202-1207. [CrossRef] [PubMed]

117. Stenvang, J.; Petri, A.; Lindow, M.; Obad, S.; Kauppinen, S. Inhibition of MicroRNA Function by AntimiR Oligonucleotides. Silence 2012, 3, 1-17. [CrossRef]

118. Pang, J.K.S.; Phua, Q.H.; Soh, B.-S. Applications of MiRNAs in Cardiac Development, Disease Progression and Regeneration. Stem. Cell Res. Ther. 2019, 10, 1-11. [CrossRef]

119. Ucar, A.; Gupta, S.K.; Fiedler, J.; Erikci, E.; Kardasinski, M.; Batkai, S.; Dangwal, S.; Kumarswamy, R.; Bang, C.; Holzmann, A.; et al. The MiRNA-212/132 Family Regulates Both Cardiac Hypertrophy and Cardiomyocyte Autophagy. Nat. Commun. 2012, 3, 1-11. [CrossRef]

120. Bernardo, B.C.; Nguyen, S.S.; Winbanks, C.E.; Gao, X.-M.; Boey, E.J.H.; Tham, Y.K.; Kiriazis, H.; Ooi, J.Y.Y.; Porrello, E.R.; Igoor, S.; et al. Therapeutic Silencing of MiR-652 Restores Heart Function and Attenuates Adverse Remodeling in a Setting of Established Pathological Hypertrophy. FASEB J. 2014, 28, 5097-5110. [CrossRef] 